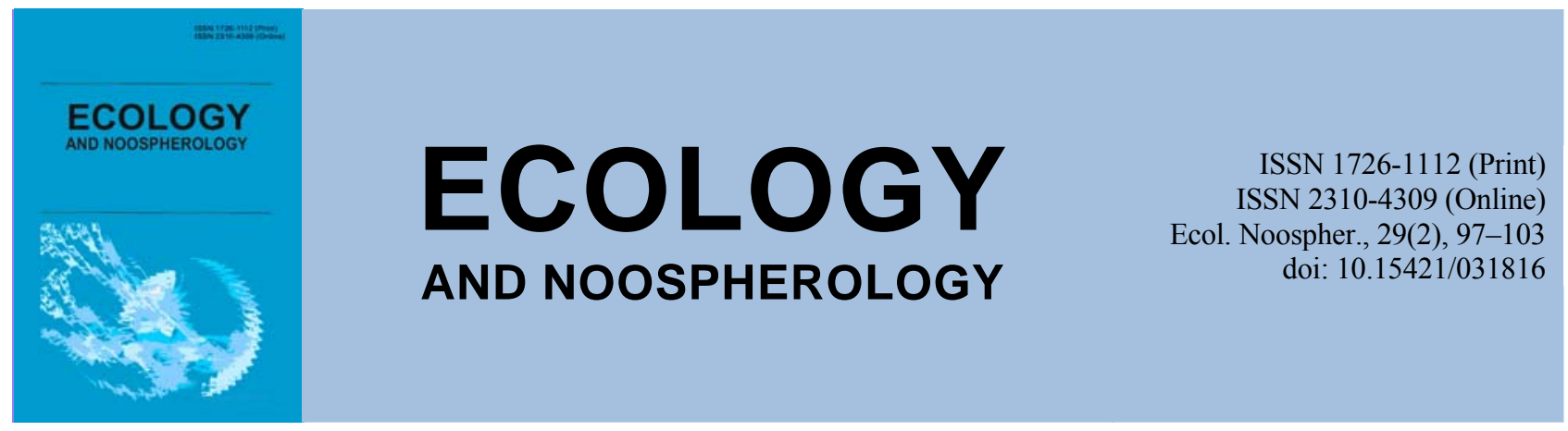

\title{
Dynamics of grass stand formation in poplar plantations on different types of reclamations of disturbed lands of Western Donbass
}

\author{
O. M. Masiuk
}

Oles Honchar Dnipro National University, Dnipro, Ukraine

Article info

Received 22.09.2018

Received in revised form

29.09.2018

Accepted 01.10.2018

Oles Honchar Dnipro

National University,

Gagarin Ave., 72, Dnipro,

49010, Ukraine.

Tel.: +38-095-401-14-65

E-mail: almas63636@gmail.com
Masiuk, O. M. (2018). Dynamics of grass stand formation in poplar plantations on different types of reclamations of disturbed lands of Western Donbass. Ecology and Noospherology, 29(2), 97-103. doi:10.15421/031816

The purpose of our research was to study the long-term dynamics of the herbage cover at different stages of growth and development of poplar plantations on the types of artificial soils of the forest reclamation area. The object of research is flora phytotoxic dumps of «Blagodatna» coal mine, where imported substrates such as sand-clay, clay loam, red-brown earth and humic soil in various combination were applied to create reclamations layer on the surface of the mine dumps (Dnipropetrovsk region, Pavlograd region). Type 1: $30 \mathrm{~cm}$ of soil mass of typical chernozem (SMTC), $50 \mathrm{~cm}$ of red-brown earth, $80 \mathrm{~cm}$ of alluvial sand-clay and sand, and deeper there is the coal mine solid; type 2: $30 \mathrm{~cm}$ of SMTC, $80 \mathrm{~cm}$ of sand, and mine solid deeper; type 3: $30 \mathrm{~cm}$ of SMTC, $60 \mathrm{~cm}$ of alluvial sand-clay, $60 \mathrm{~cm}$ of clay, and deeper there is mine solid; type 4: $40 \mathrm{~cm}$ of SMTC, $30 \mathrm{~cm}$ of red-brown earth, $40 \mathrm{~cm}$ of sand and mine solid deeper; type 5: $55 \mathrm{~cm}$ of alluvial sand-clay, deeper there is mine solid. Stationary observations were carried out in poplar plantations of 8-, 16-, 27- and 34-year-old age on permanent trial plots. They were presented with a black poplar and seven hybrid poplars. The research has established that climatic conditions, influence of surrounding phytocenoses of undisturbed lands, inheritance by pedozems of seed material of grass plants with a fertile layer of the soil set the direction of succession on the way of formation of zonal herbal group. The long-term growth of the role of the arid element indicates the formation of a structure close to the zonal flora. The formation of the flora of technical soils in poplar plantations occurs in four stages: the first is pioneer plant communities, which begins with the completion of the technical phase of reclamation and confined to the stages of forest formation; the second is a simple grouping that is associated with the development of the stand until the closure of canopy and inter-row soil cultivation; the third is a complex grouping that is fraught with pole wood stage of stand development and partial getting sparse; the fourth in our studies, is partially closed when gradually tree plants disappear and their influence disappears. In addition to the influence of tree vegetation, its age and stage of development, the formation of lower layers of biogeocenoses is significantly influenced by the conditions stipulated by the stratigraphy and the power of artificial substrates, as well as the elements of the landscape, both created initially and formed as a result of the fragmentary subsidence of the dump territory. These factors, depending on their dynamic changes, regulate correlation between various groups of biomorphs, climamorphs, trofomorphs, hygromorphs, heliomorph and zenomorphs in the grass cover. Created forest vegetation conditions on the plateau and the upper third of the dump do not meet the needs of hybrid poplars under conditions of acute shortage of moisture, which are characteristic of the steppe zone. Fast-growing poplar hybrids can be used as a pioneer culture up to 15-20 years of age.

Keywords: reclamations of disturbed lands; flora of phytotoxic dumps; biological ecomorphic analysis of the poplar plantations

\section{Динаміка формування травостою в тополевих насадженнях на різноякісних варіантах рекультивації порушених земель Західного Донбасу}




\section{О. М. Масюк}

Дніпровський національний університет імені Олеся Гончара, Дніпро, Україна

Проведено біоекоморфічний аналіз флори, який виявив особливості формування травостою в тополевих насадженнях на різних стадіях їх розвитку, культивованих в різних типах лісорослинних умов, створених штучними грунтами при рекультивації фітотоксичних відвалів. Стаціонарні спостереження проводилися в тополевих насадженнях 8-, 16-, 27- i 34-річного віку на постійних пробних ділянках. Було встановлено, що кліматичні умови, вплив оточуючих фітоценозів непорушених земель, успадкування педоземами насінного матеріалу трав'яних рослин з родючим шаром грунту задають напрям сукцесії на шляху формування зонального трав'янистого угруповання. Формування флори техноземів в тополевих насадженнях проходить в чотири стадії.

Ключові слова: рекультивація порушених земель; травостій; біоекоморфічний аналіз; Populus

\section{Вступ}

Для усунення ряду негативних екологічних наслідків, що виникають у результаті діяльності вугледобувної промисловості, у Західному Донбасі проводилася рекультивація земель: на шахтних відвалах створювалися штучні едафотопи і проводилося їх озеленення. В озелененні використовувалися понад тридцять видів і гібридів деревно-чагарникової рослинності. Особливий інтерес представляли насадження тополь, які на ранніх етапах розвитку вважалися перспективними і рекомендувалися для освоєння відновлених територій (Travleyev et al., 1988; Masyuk, 1988). На сьогоднішній момент вони знаходяться в стадії відмирання та поступової загибелі.

Метою проведених нами досліджень було вивчення багаторічної динаміки розвитку трав'яного покриву на різних стадіях росту та розвитку деревостану тополі на варіантах штучних грунтів ділянки лісової рекультивації.

\section{Об’скти та методи досліджень}

Об'єкт досліджень - флора фітотоксичних відвалів кам'яновугільної шахти «Благодатна», де для створення рекультиваційного шару застосовувалася насипка на поверхні шахтних відвалів із привезених субстратів, представлених супісками, суглинками, червоно-бурими глинами, гумусованими грунтами в різноманітному сполученні (Дніпропетровська обл., Павлоградський р-н). Териконник шахти «Благодатна» був відсипаний у 19711975 рр. і в кінцевому результаті представляє собою відвал, складений знизу «пустою» шахтною породою, на поверхні якої були створені одно-, двох- та триярусні штучні грунти на площі 11,4 га та загальним схилом в сторону русла p. Самари 6-8 $8^{\circ}$ південно-західної експозиції.

Наводимо опис варіантів рекультиваційного шару (стратиграфія зверху вниз), які визначали різні лісорослинні умови для вивчених тополевих насаджень. Варіант 1 - 30 см - грунтова маса чорнозему звичайного (ГМЧЗ), 50 см - червоно-бурий суглинок, 80 см давньоалювіальні супіски та пісок, глибше - шахтна порода; варіант 2 - 30 см ГМЧЗ, 80 см - пісок, глибше шахтна порода; варіант 3 - 30 см ГМЧЗ, 60 см давньоалювіальні супіски, 60 см - глина, глибше - шахтна порода; варіант 4 - 40 см ГМЧЗ, 30 см - червоно-бурі суглинки, 40 см - пісок, глибше - шахтна порода; варіант 5 55 см давньоалювіальні супіски, глибше - шахтна порода. Стаціонарні спостереження проводилися в тополевих насадженнях 8-, 16-, 27- і 34-річного віку на постійних пробних ділянках. Вони були представлені тополею чорною $\mathrm{i}$ сімома гібридними тополями - сортів Новоберлінський, Полтавський, Львівський, Дружба, Кременчуцький, Дивовижний, Лубенський селекції Н. В. Старової і Н. С. Крупея (Starova, 1980; Melikhov, 1985), які зростали в різних лісорослинних умовах, штучно створених на відвалі.

У процесі досліджень використано такі геоботанічні методи досліджень: стаціонарний, описовий, метод пробних площ, проведено біоекоморфічний аналіз (Belgard, 1950, 1971; Programma i metodika.., 1974; Tarasov, 2005; Yaroshenko, 1961). Видовий склад визначався за «Визначником вищих рослин України» (Opredelitel' vysshikh rasteniy Ukrainy, 1987).

\section{Результати та їх обговорення}

Перший етап комплексних досліджень проводився у восьмирічному віці насаджень (Masyuk, 1988, 1989, 1991). У результаті досліджень було встановлено, що кращі показники росту і розвитку деревостану були досягнуті тополею Новоберлінською на варіантах 3 нанесенням грунтової маси чорнозему на гірські породи. Це підтверджувалося лісотаксаційними показниками, надземною продуктивністю, вертикально-фракційним розподілом фракцій фітомаси деревостану, фізичними i водними властивостями техноземів. Інтенсивне формування трав'яного покриву описано в період стадії розвитку насадження до змикання крон 3 проведенням у міжряддях механізованої культивації верхнього шару грунту, спрямованої на поліпшення його водно-фізичних властивостей $\mathrm{i}$ боротьбу 3 травостоєм як головним конкурентом за абіотичні ресурси. Тут було враховано i вплив деревної рослинності на розвиток нижнього ярусу біогеоценозу, i освоєння травостоєм різноякісних едафічних ресурсів педоземів та літоземів (за класифікацією Yeterevskaya et al., 2008), оскільки гірські породи $\epsilon$ «стерильними» по відношенню до родючого шару чорнозему звичайного, який був джерелом насіннєвого матеріалу як правонаступник природноісторичного тіла.

Трав'яний покрив на всіх варіантах характеризувався незначною кількістю видів -7 , домінантними 3 них були Elytrigia repens (L.) Nevski, Artemisia absinthium L. 3 великою перевагою в його складі знаходилися багаторічні рослини 3 довго- та короткокореневищними підземними органами, вегетативно рухливі та вегетативно малорухливі. За класифікацією екоморф О. Л. Бельгарда (Belgard, 1950), вони були представлені геофітами та гемікриптофітами, мезотрофами, ксеромезофітами, сціогеліофітами та геліофітами. Рудеральна рослинність переважала (з незначною долею степових рослин).

Кількість видів на початкових стадіях освоєння рекультивованих територій невелика, оскільки в піонерну групу входять найбільш агресивні експлеренти, здатні швидко захоплювати штучні субстрати.

Другий етап комплексних досліджень проводився в 16-річному віці насаджень (Masyuk, 2006, 2008). До цього часу відбулася деградація насаджень, яка проявлялася в повному (тополя Дивовижна) або частковому (зрідження становило 20-40 \%) випаданні деревостану.

Найбільш стійкою виявилася тополя Новоберлінська, продуктивність якої залежала від потужності i стратиграфії штучного грунту та індивідуальних генетичних особливостей даного сорту. Гібрид проявив ознаки альтеристивного гетерозису, i продуктивність біомаси у нього формувалася за рахунок адитивного 
ефекту i адаптивних можливостей. В умовах нашого експерименту (варіант 5) в запропонованих едафічних умовах він відчував себе дискомфортно через обмеження життєвого простору i дефіцит продуктивної вологи, обумовлений незадовільними водно-фізичними властивостями штучних грунтів.

Динамічні зміни трав'яного покриву реєструвалися в період стадії розвитку насадження - жердняк, в якому сім років у міжряддях не проводились агротехнічні заходи догляду (табл. 1).

Травостій під пологом тополі Новоберлінської 16-річного віку сформований багаторічниками (коливання в межах $57-75 \%$ ) і має складну структуру. Превалюють вегетативно нерухливі (38-56 \%) та вегетативно рухливі (43-50 \%) види.

На даній території панують гемікриптофіти 43-75 \% в залежності від варіанта. Велику роль відіграють геофіти (22-29 \%) і терофіти, які переживають несприятливі умови у вигляді насіння або виводкових бруньок. Це позитивно впливає на зберігання життєздатності, але потрібен більший час для відновлення вегетативних органів за сприятливих умов.

Характеризуючи геліоморфи, прослідковується така закономірність: у міру випадання дерев 3 деревостану відбувається плавний перехід від домінування сціогеліофітів 70-63 \% (варіанти 1, 2, 3, 5; кількість дерев знаходилась у діапазоні від 1300 до 2400 на 1 га) до домінування геліофітів $71 \%$ (варіант 4; кількість дерев 610 на 1 га).

Аналізуючи флористичний склад за адаптаціями до водного режиму, відмічено сильний вплив деревостану тополі, а саме зімкнутість крон у насадженні. Зменшення цього показника, який залежить від ступеня зріджування насадження, приводить до зміни ксеромезофітної (57 \%) на мезоксерофітну рослиність $(71 \%)$. Наявність ксерофітів 11-13\% (варіанти 3, 5) та мезофітів $11 \%$ (варіант 5) має локальний характер i пов'язаний 3 незатіненими галявинами (посухостійкі умови) або 3 підпологовими місцезростаннями, де менше випаровування води.

До умов, які формуються на даних ділянках, більш адаптованими виявились мезотрофні рослини, це відмічається як на педоземах (варіанти 1-4), так і в літоземі (варіант 5). Їх часткова участь складала 56-63 \%. Треба зазначити наявність олігомезотрофів, олігомегатрофів, мегатрофів.

Аналізуючи адаптацію рослин до біогеоценозу у цілому, слід зазначити домінування рудеральних видів, оскільки антропогенний фактор суттєво впливає на склад ценозу, що залежить від штучно створених елементів ландшафту, едафотопів, деревних насаджень. Крім того, характеризується значною кількістю степових та лучних видів, що дозволяє віднести трав'яні рослини до рудерально-степово-лучних ценозів.

Третій етап комплексних досліджень проводився в 27- та 34-річному віці (Masyuk, 2013; Masyuk, Gorban, 2017). До цього часу слід констатувати повну загибель насаджень тополі, за винятком тополі Новоберлінської на варіантах 3 участю родючого шару грунту, який представлений одиничними екземплярами 3 явними ознаками суховерхості.

У 27-річному віці експериментальні насадження мали свої флористичні особливості. На літоземах травостій був повністю знищений пожежею, а на педоземах він мав наступну характеристику.

За проекційним покриттям у травостої переважав пирій повзучий $(60$ \%). В травостої переважали багаторічники $79 \%$ та дворічники - $21 \%$. Домінуючими біоморфами були стрижнекореневі (42\%), довгокореневищні (36 \%) та коренепаросткові (14 \%) види. На короткокореневищні приходилося $7 \%$. Серед біоморф за Раункієром у досліджених едафічних умовах переважали гемікриптофіти (74 \%) та геофіти (26\%). По відношенню до живлення переважали мезотрофи (64 \%) та мегатрофи (36 \%). Основну масу видів складали ксеромезофіти (50\%) та мезоксерофіти (35\%), зустрічалися гігромезофіти (8 \%) та ксерофіти (7 \%). По відношенню до світла домінуючими були геліофіти (56 \%) та сціогеліофіти (44 \%). Екологічний аналіз показав, що в травостої переважали пратанти (55\%) та рудеранти (37 \%). Степанти представлені на 8 \%.

Порівнюючи травостій під пологом тополі Новоберлінської 34-річного віку на п'яти варіантах відсипки, можна відмітити, що переважали гемікриптофіти. Це $\epsilon$ досить позитивною характеристикою, оскільки щорічний опад не тільки збагачує грунт органікою, а й захищає бруньки відновлення, що знаходяться на рівні грунту від несприятливих умов як холодною малосніжною зимою, так і посушливим літом, що $є$ характерною рисою для степів. Бруньки добре зберігаються i достатньо швидко відновлюють трав'яний покрив при настанні сприятливих умов. Установлено, що зростає роль геофітів, порівняно 3 травостоєм під пологом тополі Новоберлінської 16-річного віку. Це сприяє ще кращому зберіганню та відновленню трав'яного покриву, адже не тільки опад захищає бруньки відновлення, а й шар грунту, під яким знаходяться бруньки відновлення у геофітів.

У трав'яному покриві превалювали багаторічники (40$70 \%$, у наявності були дворічники (10-35 \%) та однорічники (5-35 \%), і це свідчить, що на даний час ценоз тут сформований і має складну структуру.

Більшість рослин на даній території за темпами вегетативного розмноження відноситься до вегетативно нерухливих (40-60 \%) та вегетативно рухливих (30-50\%) видів, які сумарно становили 82-90\%.

Аналізуючи ценоморфічний склад угруповання, можна сказати, що переважали рудеральні види, серед яких значна кількість степових та лучних видів, що дозволяє віднести ділянку до рудерально-степово-лучних ценозів. Зменшується вплив деревної рослинності на формування травостою.

Аналізуючи флористичний склад за адаптаціями до водного режиму, можна зазначити панування видів, частково вимогливих до зволоження - ксеромезофітів та мезоксерофітів. Їх сукупна частка становила 80-100 \%, що характерно для степових ценозів.

Розглядаючи трофоморфи, слід зазначити домінування мезотрофів. Це свідчить про середній вміст поживних речовин у грунті. Але зростає роль мегатрофів, і це засвідчує, що вміст доступних поживних речовин поступово зростає.

Характеризуючи геліоморфи, можна зробити висновок про превалювання видів, частково вимогливих до світла, але все ж таки тяжіючих до великої кількості світла. Велика частка участі і геліофітів - рослин, що не витримують затінення. Все це аргументується розрідженням початково створеного деревного ярусу i наявністю порослевих угруповань білої акації, клену явіра, тополі, що частково затінюють полог.

\section{Висновки}

1. Кліматичні умови, вплив оточуючих фітоценозів непорушених земель, успадкування педоземами насінного матеріалу трав'яних рослин 3 родючим шаром грунту задають напрям сукцесії на шляху формування зонального трав'янистого угруповання. Багаторічне зростання ролі аридного елемента свідчить про формування структури, близької до зональної флори.

2. Формування флори техноземів у тополевих насадженнях проходить у чотирі стадії (за Manakov et al., 2011): перша піонерне рослинне угруповання, яке починається із завершення технічного етапу рекультивації і приурочене до стадії формування деревостану; друга - просте угруповання, пов'язане із розвитком деревостану до змикання крон дерев та 


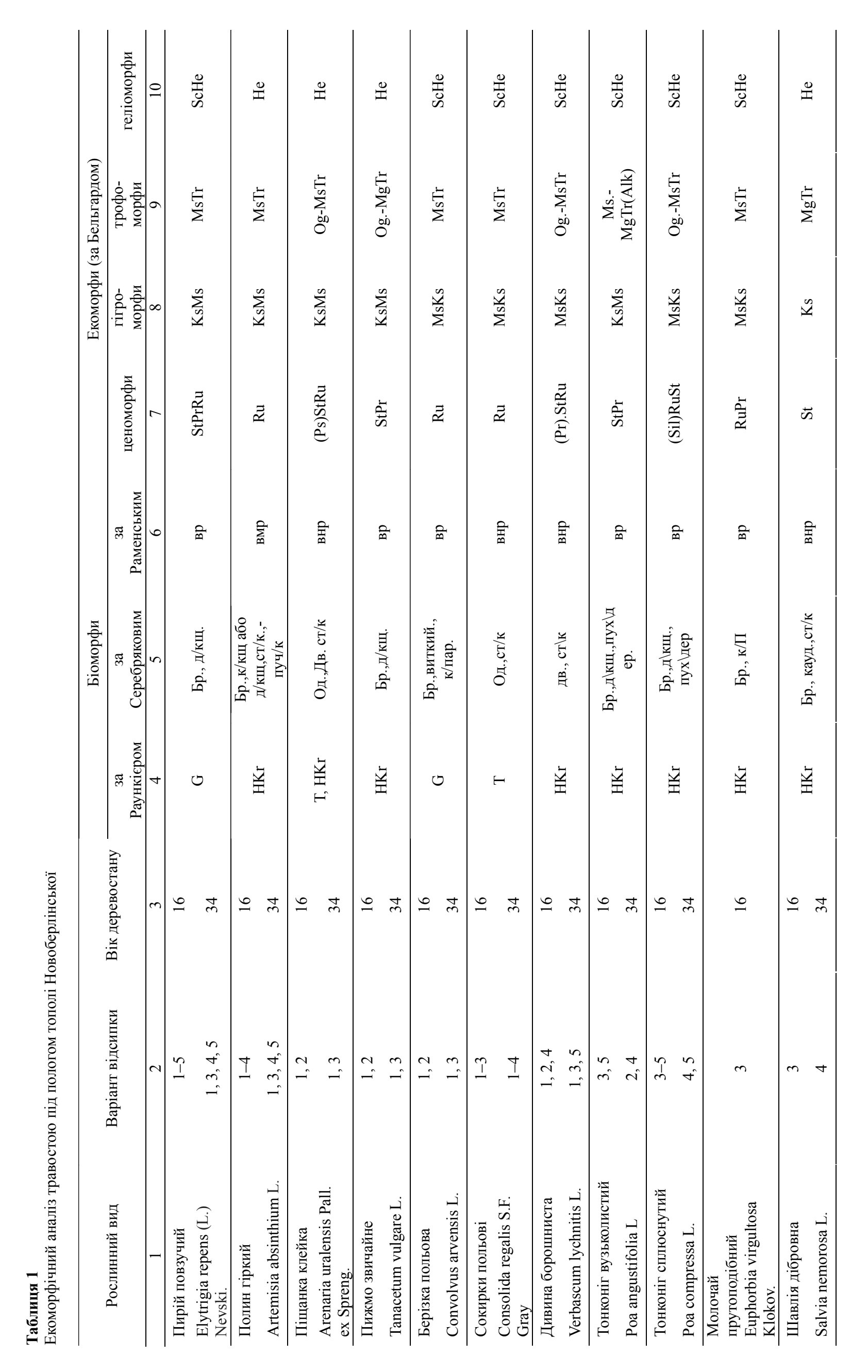




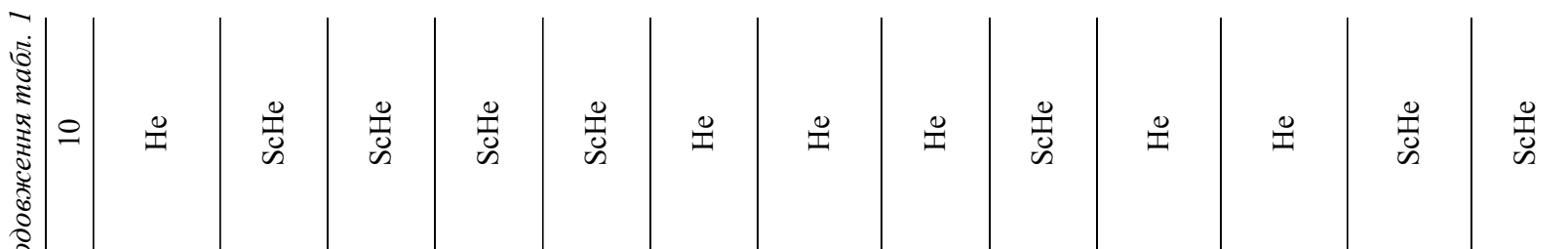

竎

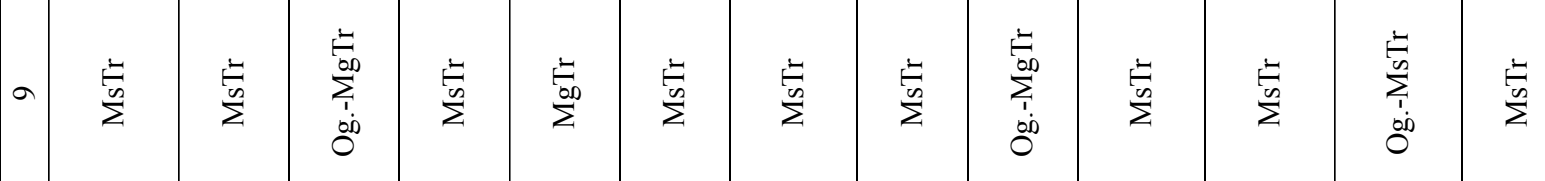

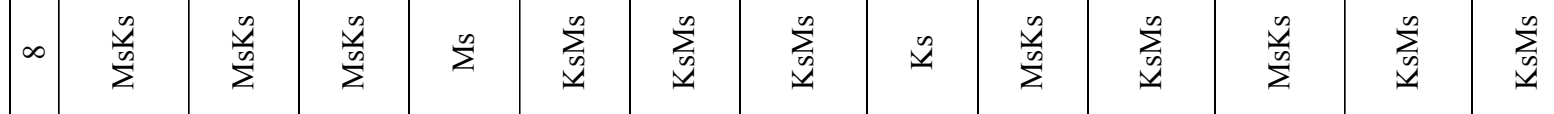

$\sim$ 旁

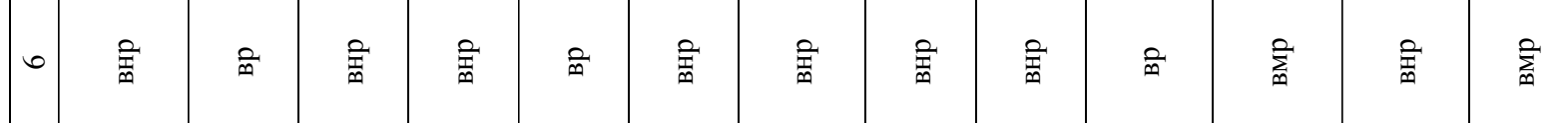

n.

ナ竞竞

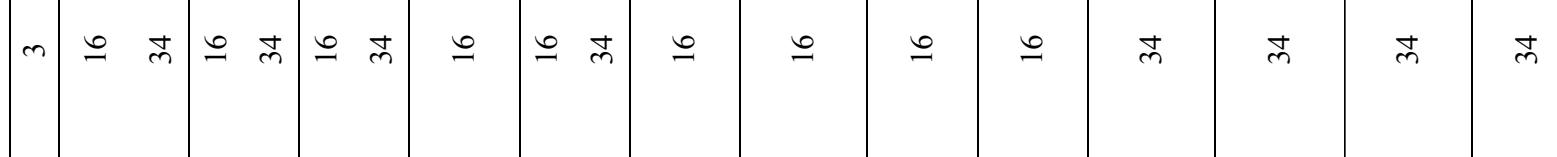

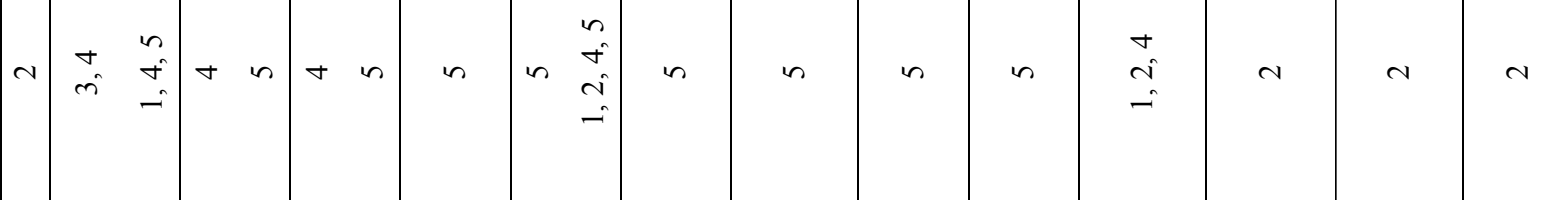

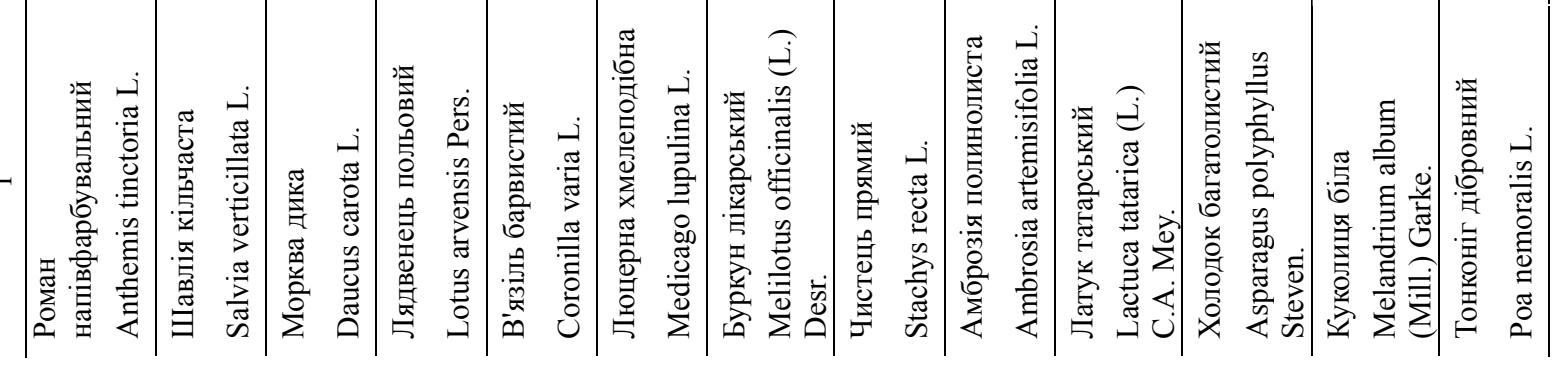




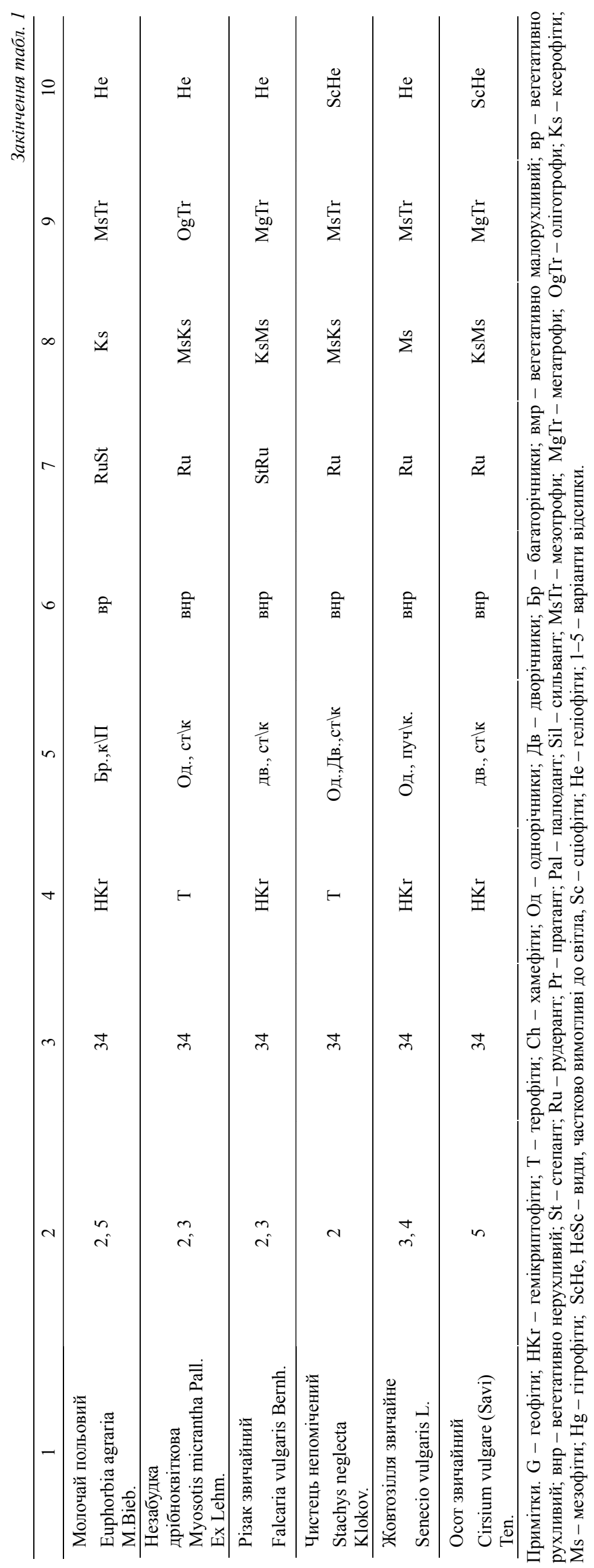


міжрядною обробкою грунту; третя - складне угруповання, пов'язане 3 жердняковою стадією розвитку деревостану та частковим його зрідженням; четверта - у наших дослідженнях частково замкнутий, коли поступово випадають деревні рослини та зникає їх вплив.

3. Крім впливу деревної рослинності, пї віку та стадії розвитку, на нижні яруси біогеоценозів велике значення для їх формування мають едафічні умови, обумовлені стратиграфією та потужністю штучних субстратів, а також елементи ландшафту, створені як від самого початку, так і сформовані в результаті фрагментарного просідання території відвалу. Ці фактори регулюють у трав'яному покриві залежно від їх динамічних змін співвідношення різних груп біоморф, клімаморф, трофоморф, гігроморф, геліоморф та ценоморф.

4. Створені лісорослинні умови на плато та верхній третині відвалу не відповідають потребам гібридних тополь в умовах гострого дефіциту вологи, які характерні для степової зони. Швидкорослі гібриди тополь можливо використовувати як піонерні культури до 15-20-річного віку.

\section{References}

Belgard, A. L. (1950). Lesnaya rastitelnost yugo-vostoka USSR [Forest vegetation of the southeast of the Ukrainian SSR]. Kiev (in Russian).

Belgard, A. L. (1971). Stepnoye lesovedeniye [Steppe forestry]. Lesnaya promyshlennost, Moscow (in Russian).

Manakov, Yu. A., Strelnikova, T. O., Kupriyanov, A. N. (2011). Formirovaniye rastitel'nogo pokrova V tekhnogennykh landshaftakh Kuzbassa [Formation of vegetation in the man-made landscapes of Kuzbass]. Novosibirsk (in Russian).

Masyuk, A. N. (1988). Produktivnost lesnykh kultur na rekultivirovannykh zemlyakh Zapadnogo Donbassa [Productivity of forest cultures on the reclaimed lands of Western Donbass]. Monitoringovyye issledovaniya lesnykh yekosistem stepnoy zony, ikh okhrana i ratsionalnoye ispolzovaniye. DSU, Dnepropetrovsk, 109-117 (in Russian).

Masyuk, A. N. (1989). Topol chernyy kak pionernaya kultura pri osvoyenii rekultivirovannykh zemel $\mathrm{v}$ Zapadnom Donbasse [Topol black as a pioneer culture in the development of reclaimed land in Western Donbass]. Ekologicheskiye aspekty okhrany i ratsional'nogo ispol'zovaniya biologicheskikh resursov. DSU, Dnepropetrovsk, 33-40 (in Russian).

Masyuk, A. N. (1991). Osobennosti nakopleniya energii i zolnykh veshchestv $\mathrm{V}$ biogeogorizontakh topolya Novoberlinskogo na rekul'tivirovannykh zemlyakh [Features of the accumulation of energy and ash substances in the biogeo-horizons of the Novoberlinsky poplar on recultivated lands]. Kadastrovyye issledovaniya stepnykh biogeotsenozov Prisamarya Dneprovskogo, ikh antropogennaya dinamika i okhrana. DSU, Dnepropetrovsk, 147-156 (in Russian).
Masyuk, A. N. (2006). Analiz pervichnoy produktivnosti 16letnego drevostoya topolya sorta Novoberlinskiy na rekultivirovannykh zemlyakh [Analysis of the primary productivity of a 16-year-old tree stand of the Novoberlinsky variety of poplars on reclaimed lands]. Gruntoznavstvo, 7(3-4), 97-110 (in Russian).

Masyuk, A. N. (2008). Osobennosti raspredeleniya kornevoy sistemy topolya novoberlinskogo $\mathrm{v}$ tekhnozemakh s raznoy stratigrafiyey $\mathrm{v}$ usloviyakh ogranichennogo edaficheskogo prostranstva [Peculiarities of the distribution of the root system of the Novoberlinsky poplar in technozems with different stratigraphy under conditions of limited edaphic space]. Gruntoznavstvo, 9(3-4), 93-100 (in Russian).

Masyuk, A. N. (2013). Prichiny gibeli topolevykh nasazhdeniy na rekultivirovannykh zemlyakh Zapadnogo Donbassa [Causes of the death of poplar plantations on the reclaimed lands of Western Donbass]. Materialy mezhdunarodnoy prakticheskoy konferentsii «Prirodno-tekhnogennyye kompleksy: rekultivatsiya i ustoychivoye funktsionirovaniye». Novosibirsk Novokuznetsk, 147-149 (in Russian).

Masyuk, O. M., Gorban, V. A. (2017). Osoblyvosti humusonakopychennya $\mathrm{v}$ tekhnozemakh pid topolevymy nasadzhennyamy $\mathrm{v}$ umovakh Zakhidnoho Donbassu [Specific features of accumulation of humus in technozems under poplar plantations in the conditions of the Western Donbass]. Gruntoznavstvo, 18(3-4), 57-66 (in Ukrainian).

Melikhov, I. S. (1987). Puti geneticheskogo uluchsheniya lesnykh drevesnykh rasteniy [Ways of genetic improvement of forest woody plants]. Nauka, Moscow (in Russian).

Opredelitel' vysshikh rasteniy Ukrainy (1987) [The determinant of higher plants of Ukraine]. Ed. Yu. N. Prokudin. Kiev (in Russian).

Programma i metodika biogeotsenoticheskikh issledovaniy (1974) [Program and methods of biogeocenotic studies]. Ed. N. V. Dylis. Moscow (in Russian).

Starova, N. V. (1980). Selektsiya ivovykh [Willow Breeding]. Moscow (in Russian).

Tarasov, V. V. (2005). Flora of Dnipropetrovsk and Zaporizhzhia regions [Flora Dnipropetrovskoyi ta Zaporizkoyi oblastey]. Lira, Dnipropetrovsk (in Ukrainian).

Travleyev, A. P., Ovchinnikov, V. A., Zverkovsky V. N. (1988). Biogeotsenoticheskiy pokrov Zapadnogo Donbassa, yego tekhnogennaya dinamika i optimizatsiya [The biogeocenotic cover of Western Donbass, its man-made dynamics and optimization]. Dnepropetrovsk (in Russian).

Yaroshenko, P. D. (1961). Geobotanika. Osnovnyye ponyatiya, napravleniya i metody [Geobotany. Basic concepts, directions and methods]. Moscow, Leningrad (in Russian).

Yeterevskaya, L. V., Momot, G. F., Lechtier, L. V. (2008). Rekultyvovani hrunty: pidkhody do klasyfikatsiyi i systematyky [Recultivated soils: approaches to classification and systematics]. Gruntoznavstvo, 9(3-4), 147-150 (in Ukrainian). 